\title{
PALYNOLOGY AND PALAEOCOMMUNITIES OF THE PALEOGENE OF ARGENTINA
}

\author{
MIRTA QUATTROCCHIO \\ CONICET, Universidad Nacional del Sur, San Juan 670 (8000), Bahía Blanca, Argentina. \\ mquattro@criba.edu.ar
}

\begin{abstract}
Two major paleophytogeoprovinces based on the palynological record at the genus or species level and at the palaeocommunity level are recognized for the Danian of Argentina. The presence of Verrustephanoporites simplex (Ulmaceae) pollen in the north is associated mostly with tropical and subtropical families, while Nothofagidites pollen in the south is mostly associated with temperate families. In the centralnorthwest of Argentina, a subprovince with elater bearing pollen (Mtchedlishvilia) is recognized. Warm and humid climatic conditions are indicated for the Ulmaceae Phytogeoprovince and more temperate conditions for the Phytogeoprovince of Nothofagidites. Tropical to subtropical communities are recognized at the Early Eocene, being later replaced by "mixed forest" with both Neotropical and Antarctic elements, which occupied most of the emerged lands. Great paleogeographic and tectonic events affected Patagonia during the Oligocene and even more clearly at the Early Miocene, when an expansion of open vegetation patches with Chenopodiaceae, Ephedraceae, Asteraceae and Poaceae is recorded. These changes are interpreted as a consequence of strong arid trends related to the final uplift of the Andes, the formation of the West Antarctic ice cap, intensification of the cold Humboldt Current and the South Pacific Subtropical Anticyclone, as well as the beginning of the continental glaciation in Patagonia.
\end{abstract}

Key words: Palynology, vegetal palaeocommunities, Paleogene, Argentina.

\begin{abstract}
RESUMO - Com base no registro palinológico em nível de gênero ou espécie e das paleocomunidades, se reconhecem duas paleofitogeoprovíncias no Daniano da Argentina. A presença de Verrustephanoporites simplex (Ulmaceae) no norte está associada, principalmente, com famílias tropicais e subtropicais, enquanto que Nothofagidites, no sul, está associado, principalmente, com comunidades vegetais temperadas. No centro e noroeste da Argentina, se distingue uma subprovíncia com grãos de pólen elaterados (Mtchedlishvilia). Condições climáticas quentes e úmidas são interpretadas para a Fitogeoprovíncia de Ulmaceae e mais temperadas para a Fitogeoprovíncia de Nothofagidites. No início do Eoceno estão presentes comunidades tropicais a subtropicais, que logo são substituídas por uma "flora mista" com elementos neotropicais e antárticos ocupando a maior parte das terras emersas. Grandes eventos paleogeográficos e tectônicos afetaram a Patagônia durante o Oligoceno e mais claramente no início do Mioceno, onde se registra a expansão da vegetação indicadora de condições abertas: Chenopodiaceae, Ephedraceae, Asteraceae y Poaceae. Estas mudanças são interpretadas como conseqüências da forte tendência a aridez relacionada com o levantamento final dos Andes, da formação da calota Antártica Ocidental e da intensificação da corrente fria de Humboldt e do Anticiclone Subtropical do Pacífico Sul, assim como do início da glaciação continental na Patagônia.
\end{abstract}

Palavras-chave: Palinología, paleocomunidades vegetais, Paleógeno, Argentina.

\section{INTRODUCTION}

The aim of this paper is to distinguish and characterize palynological assemblages of the Paleogene of southern South America. The paradigm of complexity, i.e. the systemic view of the world, is the most adequate theoretical reference to study the environment (Rojero, 2000). The Paleogene palynofloras are explained from a systemic and evolutionary point of view. The pattern of change of the Paleogene forest is outlined and discussed in the light of external and internal factors. Forests are seen as non linear, dynamic systems that are, at any point in time, unique and changing. External factors include: climate, eustatic sea level, tectonic, soil development and even planetary effects. Internal processes of forest dynamics include competition among existing species, and interactions between existing species and potential invading species (Bennett \& Willis, 1995).

Important contributions to the understanding of the history of southern South American forests are: Menéndez (1971), Volkheimer (1971), Romero (1978, 1986), Axelrod et al. 
(1991), Hinojosa \& Villagrán (1997), Villagrán \& Hinojosa (1997) and Palazzesi et al. (2003). The stratigraphic distribution of selected sporomorphs from the Late Cretaceous-Oligocene from several basins in Argentina, Chile and Antarctica was presented as a range chart in Ruiz et al. (1999). Late Cretaceous palynology is updated. A brief consideration of the Mesozoic-Cenozoic palaeogeographic and geodynamic evolution of southern South America is also given. For the understanding of the Paleogene stratigraphy see Quattrocchio \& VolKheimer (1990, 2000a) for Salta Group basin, and Malumián (1999) for Colorado Basin and Patagonia.The Figure 1 represents the Danian phytogeographic provinces in Argentina

\section{PALYNOLOGICAL ASSEMBLAGES}

\section{Late Cretaceous}

Sedimentary accumulation during the Late Cretaceous was characterized by a trend towards enlargement of depositional sites and an increase in the amount of marine influence (Uliana \& Biddle, 1988). The Late Cretaceous flooding of the Argentine margin during a period of tectonic quiescence, when the continental interior was devoid of large topographic barriers, produced a spectacular increase in the size of the areas under marine influence (e.g., Malumián et al., 1983; Salfity et al., 1985).

Senonian beds in the Salta Group Basin, northern Argentina (Quattrocchio et al., 2005), dated by dinosaur and radiometric evidence, yielded the first record of a Late Senonian palynoflora. In addition to typical Mesozoic taxa such as Classopollis spp., Todisporites major Couper, there were found some palynomorph taxa of species previously observed only in younger sediments (Paleogene), and at lower latitudes of tropical South America and tropical Africa (e.g. Retitrescolpites saturum (Gonzalez) Jaramillo \& Dilcher, Retistephanocolpites regularis Hoeken-Klinkenberg).

A plausible explanation for those Paleocene and Eocene taxa in common with tropical Africa and the Neotropics could be that they could have been originated in subtropical areas during the Late Cretaceous, when the two continents were still close to each other. Then, due to the Paleocene-Eocene climatic change, they migrated into tropical regions and consequently, appeared in the tropical fossil record. This hypothesis was postulated by Jaramillo \& Dilcher (2001:177) and confirmed in the Salta Group Basin (Quattrocchio et al., 2005).

The presence of indicators of tropical and subtropical forests (Ulmaceae, Bombacaceae), associated with low frequency marine dinoflagellates indicates warm and humid areas near the coast, with shallow lacustrine environments (Salviniaceae, Zygnemataceae) and some marine influence (?Thalassiphora sp.).

The palynological record in southern South America and western Antarctica is associated with Nothofagidites spp. in the "Nothofagidites Microfloral Province". The oldest records of the genus Nothofagidites ("fusca" and "menziesi" types) are from Fortin General Roca, Río Negro Province,
Middle Maastrichtian (Romero, 1973:301). Grapnelispora evansi Stover \& Partridge characterized the Upper Campanian/Maastrichtian of the Neuquén Basin (Allen and Jagüel formations, Palamarczuk \& Gamerro, 1988), including the Tertiary boundary in Antarctica (Macellari et al., 1987) in the López de Bertodano Formation. Palamarczuk \& Gamerro (1988) considered that $G$. evansi was associated with transitional to continental environments.

Grapnelispora loncochensis Papú (= Grapnelispora sp. 1 in Sepúlveda et al., 1989) is reported for the Late Cretaceous in the Neuquén Basin, the central valley of Chubut, and Río Negro Province (Papú, 1993). Recently, Prámparo \& Papú (2003) reported Grapnelispora loncohensis associated with Bryophyta, Pteridophyta, Gymnospermae (Classopollis, Cyclusphaera and Callialasporites) and Angiospermae (Liliacidites kaitangataensis Couper, Rousea patagonica Archangelsky, Verrustephanoporites simplex Leidelmeyer, among others) in the Neuquén Basin (Cerro Butaló, Mendoza).

Barreda et al. (2004) analyzed the spores and pollen grains of the Jagüel Formation (Neuquén Basin) containing the Cretaceous-Paleogene (K/P) boundary. The Neuquén data support the idea of a global decline in vegetation at the K/P boundary. Close to the boundary, the absolute number of terrestrial palynomorphs decrease. Above the boundary, Classopollis and fern spores are recorded. Angiosperm groups (Liliaceae, Ulmaceae, Loranthaceae, Olacaceae, and others) became highly reduced in abundance the Proteaceae being the group that suffered the greatest loss.

Some of these families were present in the Danian of Salta Group (e.g., Ulmaceae), Colorado Basin (e.g., Ulmaceae, Loranthaceae, Liliaceae) and Patagonia (e.g., Ulmaceae). Probably the global event of the K/P boundary could be also related to regional or local effects that produced extinction and also migration of taxa.

In Santa Cruz province, the Maastrichtian Age is documented through the record of dinoflagellates [Manumiella druggii (Lage) Bujak \& Davies, and Eisenackia circumtabulata Drugg] and Grapnelispora loncochensis Papú (Guler et al., 2003).

During the Late Cretaceous and Paleogene, a southern high latitude, cool temperate biogeographic province extended from Patagonia in South America, across Antarctica (mainly Western Antarctica) to New Zealand and southeastern Australia. This Weddellian Province (Zinsmeister 1979, 1982) included shallow marine faunas, as well as terrestrial biotas (Case, 1988, 1989; Askin, 1989; Baldoni \& Askin, 1993). The Weddellian vegetation was characterized by podocarpaceous conifer/Proteaceae/Nothofagus forest (and especially Lagarostrobus/Phyllocladidites mawsonii pollen) which dominated the floras during the Campanian through Paleocene. Nothofagus was more abundant in the Eocene (Baldoni \& Askin, 1993).

The lower Lefipán Formation at Barranca de los Perros, Chubut Province, is considered Maastrichtian in age, based on (Association I) invertebrate faunas (Medina et al., 1990) and palynofloras. The Lefipán flora is considered marginally 


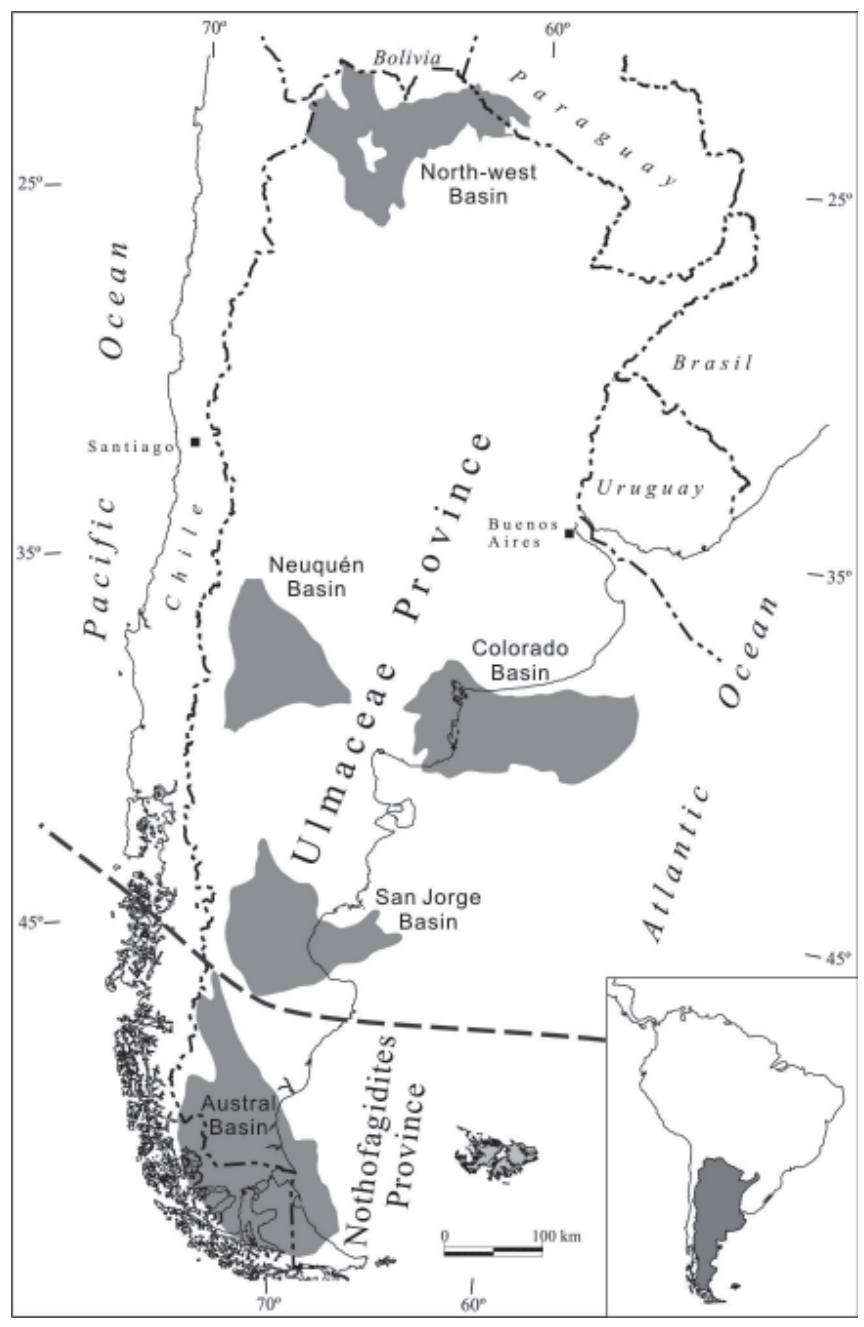

Figure 1. Danian phytogeographic provinces in Argentina (from Quattrocchio \& Volkheimer, 2000 b).

Weddellian as it contains some endemic Weddellian Province species, but does not reflect the "typically Weddellian" forest vegetation (Baldoni \& Askin, 1993).

\section{Paleogene}

During the Paleocene ( 65-55 Ma), Antarctica was in high-latitude position as it had been through the Middle and Late Mesozoic. The continent was largely non-glaciated and it was joined to Australia (Kennett, 1980).

The decrease of areas under marine influence seems to be the response to base level lowering related to early Tertiary global eustatic fall. During the Early Cenozoic, the Maastrichtian seaway that linked Bolivia and coastal Argentina was transformed in a series of broad alluvial plains and large lake basins. In Patagonia many areas invaded by the Late Cretaceous epineritic flooding turned into vast loess plains made up by distal pyroclastics punctuated with numerous paleosoils (Uliana \& Biddle, 1988).

According to Kennett (1980), during the Early Eocene (55 Ma) Australia began to drift northwards from Antarctica. During the Eocene (55-38 Ma) the Southern Ocean was relatively warm and Antarctica was still largely non-glaciated.
Evidence of mountain glaciation is reported for Antarctica in the Early/Middle Eocene.

Near the Eocene/Oligocene boundary the sharp climatic deterioration has been related to the formation of the Antarctic ice cover (Kennett et al., 1975) and to the appearance of a circumpolar current around Antarctica as a result of the opening of the Drake Passage (Zubakov \& Borzenkova, 1990).

\section{Continental basin of NW Argentina (Salta Group Basin)}

The grabens and positive structural elements which governed the Salta Group sedimentation controlled the landplant distribution during the Paleogene.

The continental Danian is recorded in NW Argentina, in the Tunal Formation of the Salta Group Basin (Quattrocchio et al., 1988). The pollen assemblage suggests an Early Paleocene age. Mtchedlishvilia saltenia Moroni is first recorded. An interval zone extends from the first appearance of Mtchedlishvilia saltenia to the first appearance of Rousea patagonica Archangelsky in the Mealla Formation (Quattrocchio et al., 2000). The presence of Simpsonotus (Mammalia, Henricosborniidae) in the Mealla Formation and the absence of other Casamayoran mammals allowed the correlation between Mealla Formation with the Riochican Age of Patagonia, conventionally assigned to a Middle to Late Paleocene Age (Pascual et al., 1978).

The characteristic association present in the Tunal Formation is: Mtchedlishvilia saltenia Moroni associated with Verrustephanoporites cf. simplex Leidelmeyer (Ulmaceae), Pandaniidites texus Elsik (Pandanaceae), Gemmatricolpites subsphaericus Archangelsky (Aquifoliaceae), and Clavatricolpites cf. gracilis Gonzalez Guzmán.

In the locality of Tilian, the assignment of Verrustephanoporites cf. simplex to Phyllostylon, Ulmaceae, ca. 78-88.5\% (Quattrocchio et al., 1988) in the Tunal Formation suggests a similar paleoenvironment to the present Transitional Forest (350-500 m over sea level) in the Yungas Province, Amazónico Dominion (Cabrera, 1976) where this tree is dominant. The Yungas Province has humid and warm climatic conditions, with principally summer rainfall. Consequently, these could be the climatic conditions during the deposition of the Tunal Formation. Even if the palynomorphs of the Tunal Formation from Tilian and Corralito localities suggest warm and humid climate, these conditions certainly did not prevail within the whole extension of the sedimentary basin, given that simultaneously coexisted the saline to hypersaline lacustrine system of the Olmedo Formation (Quattrocchio et al., 2005).

The Transitional Forest would be more impoverished in the "Faja Gris" of the Mealla Formation (Ulmaceae 10-29\%) with respect to that of Tunal Formation. According to palynological and sedimentological results, the analyzed profile would be located in the "calcareous pelite plain" subenvironment defined by Gómez Omil et al. (1989) for the "Faja Gris", which constitutes a rapid flood and further dissecation in an extremely shallow basin (Gomez Omil et al., 1989). The Mealla Formation was assigned to the Thanetian 
(Quattrocchio et al. 1997), considering the tectonosedimentary study of Gomez Omil et al. (1989) along with the paleofloristic changes observed during the Paleocene in Salta Group Basin (Quattrocchio et al., 1997).

A new paleogeographic change is inferred by the dominance of dry and higher montane communities (dominance of Rutaceae, Rhoipites sp. A) in the Maíz Gordo Formation (Volkheimer et al., 1984) with respect to the Mealla Formation ("Faja Gris") with alternating periods of flooding and shallowing (Quattrocchio \& Del Papa, 2000).

Temperate and humid conditions were inferred for Fajas Verdes I and II, of the Lumbrera Formation (?Middle-Late Eocene). The assemblages are dominated by elements characteristic of humid montane paleocommunities (e.g., Gymnospermae, Hamamelidaceae and Lycopodiaceae).

Elements from swamps and lakes include Onagraceae, Marsileaceae and Combretaceae (Quattrocchio et al., 2000). The quantitative variation of the Pediastrum-Botrycoccus algae reflects the lake level fluctuations (Del Papa et al., 2002).

\section{Colorado Basin}

The palynologically fertile levels of the Colorado Basin correspond to the Danian Zone P1b (Morozovella pseudobulloides) of foraminifers and WP3 (Martini, 1971) of calcareous nannoplankton.

Among the terrestrial species, Classopollis classoides dominates the spectrum (up to $80 \%$ calculated over the sum of spores + pollen), with Verrustephanoporites cf. simplex $(19.4 \%)$. The floral assemblage is also characterized by the abundance and diversity of angiosperm pollen, and by the relatively high diversity of pteridophyte spores as well as bisaccate pollen of podocarpaceous affinity. Among the pteridophytes, the spores of gleicheniaceous and cyatheaceous affinity are particularly diverse.

Paleoenvironmental conditions would be similar to those inferred for NW Argentina (Danian), with a forest of Ulmaceae (Verrustephanoporites cf. simplex) near the site of deposition of the Pedro Luro Formation and the presence of elements of the cloudy forest (Myrtaceae, Olacaceae and Palmae) and montane forest (Podocarpaceae, Rutaceae, Anacardiaceae and Haloragaceae). A palustrine environment is suggested by the presence of Mtchedlishvilia saltenia (Moroni, 1984).

The composition of the Pedro Luro Formation assemblages indicates warm paleotemperatures (subtropical/ tropical) especially due to the presence of Ulmaceae, Anacardiaceae, Aquifoliaceae, Olacaceae, Bombacaceae, Palmae, Restionaceae, among others, with the presence of temperate (Gunneraceae, Hamamelidaceae) to cool (Proteaceae, Fagaceae) elements (Quattrocchio \& Ruiz, 1999). The mixture of Normapolles and Aquilapollenites pollen types are recognized. They are not typical of those phytogeoprovinces and probably they have a southern South American origin (Ruiz, 1993).

The Upper Paleocene has not been recorded in this basin. In the ?Middle Eocene-Oligocene a mixed flora ("Paleoflora Mixta " of Romero, 1978) is documented (Guerstein et al., 1995; Hinojosa \& Villagrán, 1997). The "Paleoflora Mixta" would have originated in Patagonia by the Paleocene, developed in the Eocene, and disappeared by the Oligocene. It would have been formed by "in situ evolution ... and by migration of subtropical species from the North and cold temperate ones from the South" (Romero, 1978:209). According to Hinojosa \& Villagrán (1997), the "Paleoflora Mixta" is characterized by cold-temperate (e.g., Nothofagus, Laurelia, Lomatia), subtropical (e.g., Annona, Nectandra, Ocotea) and in situ (e.g. Schinopsis, Schinus) taxa.

\section{Patagonia}

During the Paleocene (Danian, Salamanca and Bororó formations), a vegetation dominated by tropical elements would have developed in Patagonia. The first testimonies of the Atlantic Marine ingression correspond to the Salamanca Formation (Archangelsky, 1973). The Salamanca Formation was correlated to the Pedro Luro Formation, based on the similarity of their microfloristic associations (Ruiz \& Quattrocchio, 1996). Bothe units yielded the first appearance of Rousea patagonica. The characteristic association includes: Syndemicolpites petriellai Archangelsky, Rhoipites baculatus Archangelsky, R. minusculus Archangelsky, Restioniidites pascualii Archangelsky, Polyporina romeroi Archangelsky, Ulmoideipites patagonicus Archangelsky (= Verrustephanoporites simplex Leidelmeyer), and others.

The Paleocene vegetation in SE Chubut was composed of several communities: mangrove, swamp woodland, tropical rain forest, mossy forest, "Araucaria" woodland and sclerophilous forest (or savanna). The dominant climate would have been "Cfa" type (subtropical humid) of Köppen's classification (Petriella \& Archangelsky, 1975).

Classopollis is present (up to $50 \%$ ) in Paleocene levels of Patagonia. This genus is not recorded from the Upper Paleocene upwards. Then, the extinction of the Cheirolepidaceae family occurred during the Paleocene. The absence of this genus in Upper Cretaceous sediments of Patagonia is difficult to explain considering that it is one of the dominant elements in the Lower Cretaceous paleofloristic assemblages. Probably, the ecologic conditions produced the temporal retraction of the Cheirolepidiaceae to drier montane areas. This type of environment is recorded in the Lower Paleocene of San Jorge Gulf, where it allowed the development of the last representatives of the family (Archangelsky \& Romero, 1974). On the other hand, Classopollis was recently discovered in in the Maíz Gordo Formation of the Salta Group (Thanetian, Upper Paleocene), being a northward migration of this genus (Petrulevicius, 1996; Quattrocchio \& Del Papa, 2000).

There was a general retraction of the genus Nothofagidites during the Lower Paleocene and increase during the Upper Paleocene (Thanetian, Río Chico Formation), and a great expansion during the Eocene (Río Turbio Formation). Probably due to new habitats related with the first movements that lifted the Andes Ridge ( Romero, 1973). The Río Turbio Formation (late Middle Eocene) in western Patagonia bears mostly Gymnospermae, Fagaceae, 


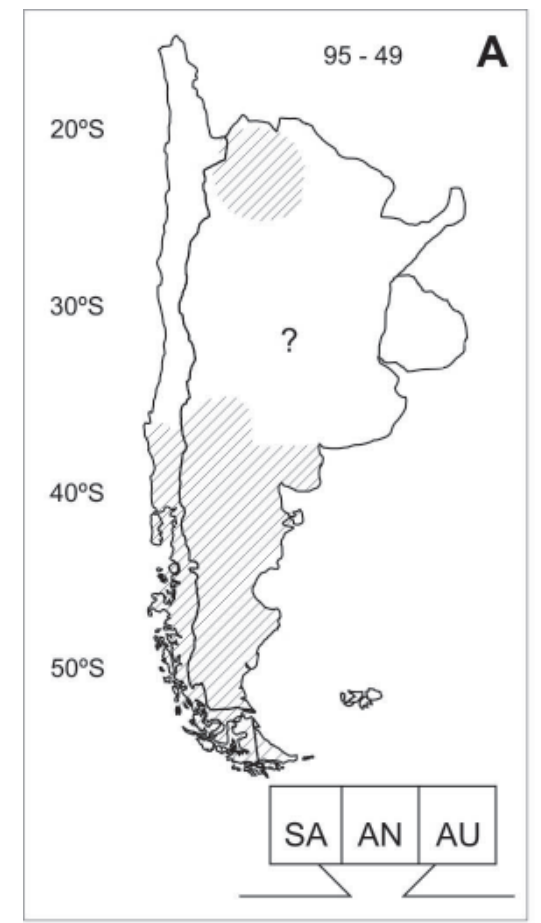

1

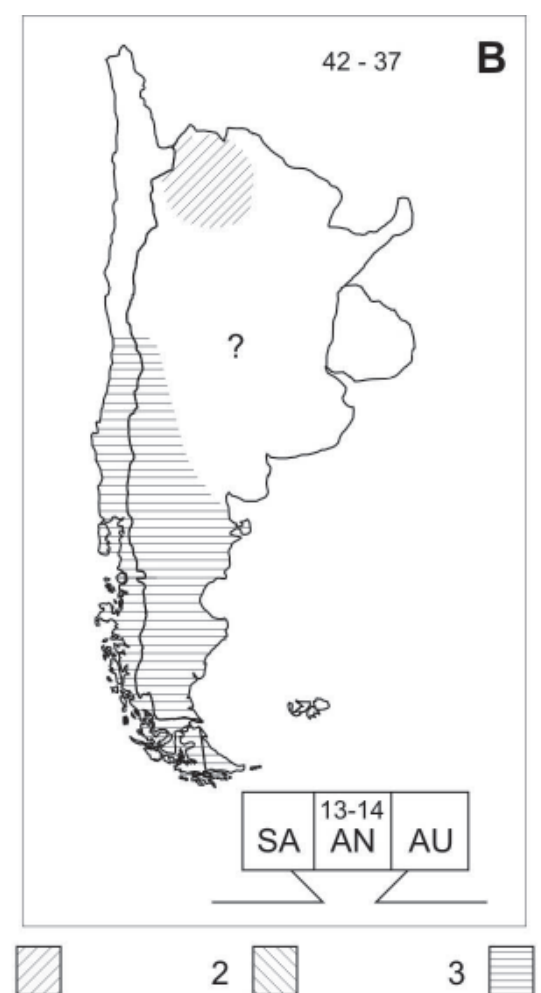

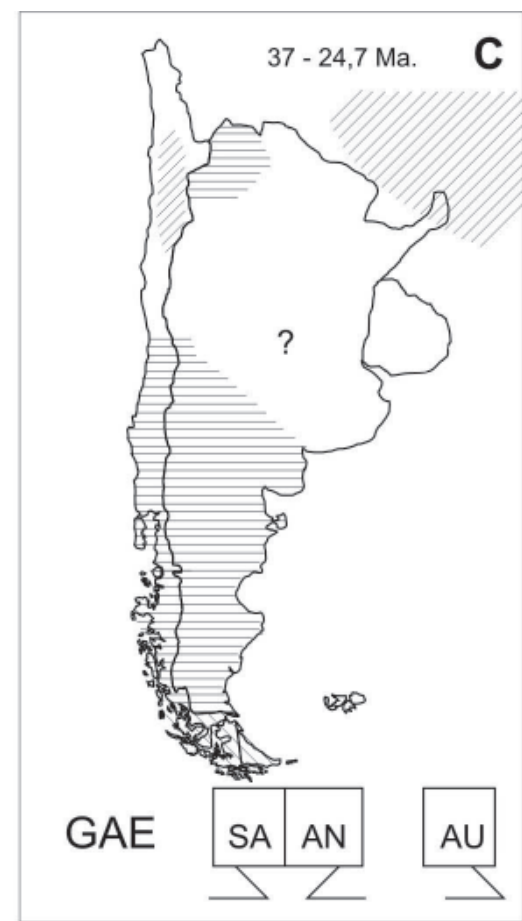

Figure 2. Evolution of Late Cretaceous and Paleogene floras in Southern South America: A, for 95-49 Ma; B, 42-37 Ma; and C, 37-24.7 Ma (modified from Hinojosa \& Villagrán, 1997). Paleofloras: 1.Tropical, 2. Antárctica, 3. Mixta. Abbreviations: A, Australia; AN, Antarctica; GAE, Glaciation in East Antarctica; SA, South America.

Myrtaceae, Proteaceae, and spores with few species of angiosperms (Archangelsky, 1972; Romero, 1977; Romero \& Zamaloa, 1985). Hinojosa \& Villagrán (2005) classified this taphoflora as Mixed Paleofloras.

In the Paleogene Huitrera Formation of NW Patagonia, Melendi et al. (2003) recorded microfloras without Nothofagidites of Early Eocene age, and others dominated by Nothofagidites ("brassii " and "fusca" groups) of Middle to Late Eocene age. These authors recognized a 'mixed flora' for the Middle to Late Eocene.

Tropical elements were recognized for the Early Eocene, being later replaced by "mixed" forest with both Neotropical and Antarctic elements occupying most of the emerged lands (Palazzesi et al., 2003).

The palynological assemblage recovered from the basal pelitic section of the San Julián Formation, (?Late EoceneOligocene), in Cabo Curioso area, Santa Cruz province, is composed of continental palynomorphs that reflect a forest dominated by Fagaceae, Myrtaceae, Podocarpaceae and Palmae, developed under a temperate to warm-temperate and humid climate (Nañez et al. in preparation). This palynological assemblage reflects also the "Mixed Paleoflora" of Romero (1978).

The Slogget Formation, in Bahía Slogget, Tierra del Fuego Island (Olivero et al., 1998), probably Late Eocene in age, is excluded from the suggested distribution of the "mixed flora", due to the presence of beech, podocarpacean and proteacean pollen, fern and fungal spores and fresh water algae, of temperate to cold/temperate and humid conditions. The palynological assemblage of Estancia La Golondrina (Tierra del Fuego Island) is closely related to those described from the Slogget Formation. Correlations with Bahía Slogget outcrops support a NNW trending tectonic corridor, developed on pre-Paleogene units that controlled the deposition of continental sequences during the Eocene/ Oligocene in the Fueguian Cordillera (Rosello et al., 2004). Menéndez \& Caccavari de Filice (1975) also described a microflora dominated by Nothofagidites for the Late Eocene/ Oligocene of Tierra del Fuego Island.

In the Oligocene, a community dominated by Myrtaceae, Palmae and Araucariaceae trees with Podocarpaceae and Fagaceae is recognized in San Julián Formation at Playa La Mina, Santa Cruz Province (Barreda, 1997). However the presence of small amounts of Anacardiaceae, Malvaceae, Symplocaceae, Ephedraceae, Poaceae, Asteraceae and Chenopodiaceae suggest the development of a local open vegetation. The spore-pollen assemblage suggests warm and humid conditions. These conditions are also inferred for the Late Oligocene in the southern part of San Jorge Gulf, Santa Cruz Province (Barreda \& Palamarczuk, 2000). Similar palynological assemblages are recognized in the lower part of the Centinela Formation (Oligocene-Miocene boundary) in southwestern Santa Cruz Province (Guerstein et al., 2004).

Hence, the traditional Cenozoic vegetational evolutive scheme where the "Paleoflora Mixta"was replaced by a cold temperate forest South of $40^{\circ}$ latitude, since the Late Eocene has changed (Palazzesi et al., 2003). 
Hinojosa \& Villagran (2005) using leaf physiognomical analysis for Cenozoic Mixed fossil floras of Chile and Argentina, postulated that the Mixed Paleoflora evolved in a subtropical climate that extended as far south as $40^{\circ} \mathrm{S}$ (until at least the Middle Miocene), with relatively warm temperatures and high annual rainfall with little seasonal variations.

Large paleogeographic and tectonic events affected Patagonia during the Oligocene and even more clearly the Early Miocene, when an expansion of open vegetation patches with Chenopodiaceae, Ephedraceae, Asteraceae and Poaceae was recorded (Palezzesi et al., 2003).

\section{DISCUSSION}

The palynological assemblage from Vilches (Salta Group Basin) cannot be placed into any of the defined palynofloristic provinces for the Late Cretaceous. Based on Traverse's map of Cretaceous palynofloral provinces (1988) it could be placed geographically near the boundary between the Palmae Province and the Nothofagidites Province.

Based on the palynological record at the genus or species level and at the paleocommunity level, two major paleophytogeoprovinces could be recognized during the Danian in Argentina. The presence of Verrustephanoporites simplex (Ulmaceae) pollen in the north is associated mostly with tropical and subtropical families and Nothofagidites pollen in the south is mostly associated with temperate families. A subprovince with elater bearing pollen (Mtchedlishvilia) could be distinguished in centralnorthwest of Argentina. Warm and humid climatic conditions are inferred for the Ulmaceae Phytogeoprovince and more temperate conditions for the Phytogeoprovince of Nothofagidites (Quattrocchio \& Volkheimer, 2000b).

Since the ?late Middle-Late Eocene a mixed flora (Paleoflora Mixta) is documented in Colorado, San Jorge and Austral (excluding Tierra del Fuego) basins. It is also recorded in Precordillera Central, San Juan Province (Prámparo et al., 1995; 1996).

A subtropical flora with temperate elements is identified in the Lumbrera Formation of Salta group Basin.

During the Oligocene the presence of Anacardiaceae, Malvaceae, Symplocaceae, Poaceae, Asteraceae and Chenopodiaceae suggests the development of open vegetation in Patagonia. Most of these families are present also in the Colorado Basin.

Hinojosa (2005) proposed four new paleofloras (Gondwanic, Subtropical Gondwanic, Mixed and Subtropical Gondwanic) based on taphofloras found mainly in Chile and Argentina.

The Gondwanic and Subtropical Gondwanic Paleofloras were associated with warm and humid tropical conditions during the Paleocene/Eocene. A climate shift towards temperate-drier conditions at the end of the Eocene and early Oligocene, is inferred by the prevailing Mixed Paleofloras. The mid Miocene climatic optimum is recorded through the development of Neogene Subtropical Paleoflora.
Hinojosa \& Villagran (1997) postulated the presence of a Subtropical Paleoflora without Nothofagus in central Chile and northern Argentina during the Middle and Upper Miocene, that included taxa with disjunct distributions in the present. These include taxa inhabiting today the sclerophyllous forest from central Chile and the Yungas forest of the NW Argentina and Bolivia, as well as the subtropical forest of southern Brazil.

\section{REFERENCES}

Archangelsky, S. 1972. Esporas de la Formación Río Turbio (Eoceno), Prov. de Santa Cruz. Revista Museo de La Plata, (nueva serie), Paleontología, 6:65-100.

Archangelsky, S. 1973. Palinología del Paleoceno de Chubut. 1. Descripciones sistemáticas. Ameghiniana, 10(4):339-399.

Archangelsky, S. \& Romero, E.1974. Polen de gimnospermas (coníferas) del Cretácico Superior y Paleoceno de Patagonia. Ameghiniana, 11(3):217-236.

Askin, R.A. 1989. Endemism and heterochroneity in the Late Cretaceous (Campanian) to Paleocene palynofloras of Seymour Island, Antarctica: Implications for origins, dispersal and palaeoclimates of southern floras In: J.A. Crame (ed.) Origins and Evolution of the Antarctic Biota, Geological Society Special Publication, p. 107-119.

Axelrod, D.; Kalin-Arroyo, M.T. \& Raven, P. 1991. Historical development of temperate vegetation in the Americas. Revista Chilena de Historia Natural, 64:413-446.

Baldoni, A.M. \& Askin, R.A. 1993. Palynology of the lower Lefipán Formation (Upper Cretaceous) of Barranca de Los Perros, Chubut province, Argentina. Palynology, 17:241-264.

Barreda, V.D. 1997. Palinoestratigrafía de la Formación San Julián en el área de Playa La Mina (Provincia de Santa Cruz), Oligoceno de la cuenca Austral. Ameghiniana, 34(3):283-294.

Barreda, V. \& Palamarczuk, S. 2000. Palinoestratigrafía de depósitos del Oligoceno tardío-Mioceno en el área sur del Golfo San Jorge, provincia de Santa Cruz. Ameghiniana, 37(1):103-117.

Barreda, V.; Palamarczuk, S. \& Chamberlain Jr., J.A. 2004. Vegetational Disruption at the Cretaceous/Paleogene Boundary in Neuquén, Argentina: Evidence from Spores and Pollen. In: REUNIÓN ARGENTINA DE SEDIMENTOLOGÍA, 10, 2004. Resúmenes Contribuciones, San Luis, p. 185-186.

Bennett, K.D. \& Willis, K.J. 1995. The role of ecological factors in controlling vegetation dynamics on long temporal scales. Giornale Botanico Italiano, 129(1):243-254.

Cabrera, A. 1976. Regiones Fitogeográficas Argentinas. Enciclopedia Argentina de Agricultura y Jardinería, 2(1):1-85.

Case, J.A. 1988. Paleogene floras from Seymour Island, Antarctic Peninsula. In: R.M. Feldmann \& M.O. Woodburne (eds.) Geology and Paleontology of Seymour Island, Antarctic Peninsula, Geological Society of America, p. 523-530.

Case, J.A. 1989. Antarctica: the effect of high latitude heterochroneity on the origin of the Australian marsupials. In: J.A. Crame (ed.) Origins and Evolution of the Antarctic Biota, Geological Society Special Publication, p. 217-226.

Del Papa, C.; García, V. \& Quattrocchio, M. 2002. Sedimentary facies and palynofacies assemblage in Eocene perennial lake, Lumbrera Formation, northwest Argentina. Journal of South American Earth Sciences, 15:553-569.

Gómez Omil, R.J.; Boll, A. \& Hernández R.M. 1989. Cuenca CretácicoTerciaria del Noroeste Argentino (Grupo Salta). In: G. 
Chebli \& L. Spalletti (eds.) Cuencas Sedimentarias Argentinas, Serie Correlación Geológica 6:43-64.

Guerstein, R.G.; Quattrocchio, M.; Deschamps, C. \& Ruiz, L. 1995. Cenozoic (pre-Pliocene) paleoenvironmental trend based on palynomorphs from the Colorado basin, Argentina. Asociación Paleontológica Argentina, Publicación Especial, 3:63-73.

Guler, M.V.; Guerstein, G.R.; Papú, O.; Casadío, S. \& Marensi, S. 2003. Palinomorfos del Maastrichtiano de la Formación Calafate, sudoeste de Santa Cruz, Argentina. Ameghiniana (Resúmenes), 40(4):88R.

Guerstein, G.R.; Guler, M.V. \& Casadío, S. 2004. Palynostratigraphy and palaeoenvironments across the Oligocene- Miocene boundary within the Centinela Formation, southwestern Argentina. In: A.B. Beaudoin \& M.J. Head (eds.) The Palynology and Micropaleontology of Boundaries, Geological Society Special Publication, p. 325-343.

Hinojosa, L.F. 2005. Cambios climáticos y vegetacionales inferidos a partir de paleofloras cenozoicas del sur de Sudamérica. Revista Geológica de Chile, 32(1):95-115.

Hinojosa, L.F. \& Villagrán, C. 1997. Historia de los bosques del sur de Sudamérica. I: antecedentes paleobotánicos, geológicos y climáticos del Terciario del cono sur de América. Revista Chilena de Historia Natural, 70:225-239.

Hinojosa,L.F. \& Villagrán, C. 2005. Did South American Mixed Paleofloras evolve under thermal equability or in the absence of an effective Andean barrier during the Cenozoic?. Palaeogeography, Palaeoclimatology, Palaeoecology, 217:1-23.

Jaramillo, C.A.\& Dilcher, D.L.2001. Middle Paleogene palynology of Central Colombia, South America: A study of pollen and spores from tropical latitudes. Palaeontographica, Abt. B. 258(4-6):87-213.

Kennett, J.P. 1980. Paleoceanographic and biogeographic evolution of the Southern Ocean during the Cenozoic, and Cenozoic microfossil datums. Palaeogeography, Palaeoclimatology, Palaeoecology, 31(2-4):123-152.

Kennett, J.P.; Houltz, R.E.; Andrews, P.B.; Edwards, A.R.; Gostín, V.A.; Hajos, M.; Hampton, M.A.; Jenkins, D.G.; Margolis, S.V.; Ovenshine, A.T. \& Perchnielsen, K. 1975. Antarctic glaciation and the development of the Circum-Antarctic Current. Initial Reports of the Deep Sea Drilling Project, 29:1155-1179.

Macellari, C.; Askin, R. \& Huber, B. 1987. El límite Cretácico\Terciario en la Península Antarctica. In: CONGRESO GEOLÓGICO ARGENTINO, 10, 1987. Actas, 3:167170.

Malumián, N. 1999. La sedimentación y el volcanismo terciarios en la Patagonia Extraandina. 1. La sedimentación en la Patagonia Extraandina. Instituto de Geología y Recursos Minerales, Geología Argentina, Anales, 29(18):557-612.

Malumián, N.; Nullo, F.E. \& Ramos, V.A. 1983. The Cretaceous of Argentina, Chile, Paraguay and Uruguay. In: M. Moullade \& A.E.M. Nairn (eds.) The Phanerozoic Geology of the World. II. The Mesozoic B, Elsevier, p. 265-304.

Martini, E. 1971. Standard Tertiary and Quaternary calcareous nannoplancton zonation. In: CONFERENCE PLANKTONIC MICROFOSSILS, 2, 1971. Proceedings, Roma, 2:739-786.

Medina, F.A.; Camacho, H.H. \& Malagnino, E.C. 1990. Bioestratigrafía del Cretácico superior-Paleoceno marino de la Formación Lefipán, Barranca de Los Perros, Río Chubut, Chubut. In: CONGRESO ARGENTINO DE PALEONTOLOGÍA Y BIOESTRATIGRAFÍA, 5, 1990. Actas, Tucumán, Serie Correlación Geológica, 7:137-142.

Melendi, D.L.; Scafati, L.H. \& Volkheimer, W. 2003.
Palynostratigraphy of the Paleogene Huitrera Formation in NW Patagonia, Argentina. Neues Jahrbuch für Geologie Paläontologie, Abhandlungen, 228(2):205-273.

Menéndez, C. 1971. Floras terciarias de la Argentina. Ameghiniana, 8:357-370.

Menéndez, C. \& Caccavari de Filice, M. 1975. Las especies de Nothofagidites (polen fósil de Nothofagus) de sedimentos terciarios y cretácicos de Estancia La Sara, norte de Tierra del Fuego, Argentina. Ameghiniana, 12(2):165-183.

Moroni, A.M. 1984. Mtchedlishvilia saltenia $\mathrm{n}$. sp. en sedimentitas del Grupo Salta, provincia de Salta. In: CONGRESO ARGENTINO DE PALEONTOLOGÍA Y BIOESTRATIGRAFÍA, 3, 1982. Actas, Corrientes, p. 129-139.

Olivero, E.B., Barreda, V., Marenssi, S.A., Santillana, S.N. \& Martinioni, D.R. 1998. Estratigrafía, sedimentología y palinología de la Formación Sloggett (Paleógeno continental), Tierra del Fuego. Revista de la Asociación Geológica Argenti$n a, \mathbf{5 3}(4): 504-516$.

Palamarczuk, S. \& Gamerro, J.C. 1988. Grapnelispora evansii, Megaspora del Cretácico superior (? Campaniano superior Maastrichtiano) de Argentina y Antártida. In: CONGRESO ARGENTINO DE PALEONTOLOGÍA Y BIOESTRATIGRAFÍA, 4, 1988. Actas, Mendoza, 3:87-93.

Palazzesi, L.; Barreda, V. \& Prieto, A.R. 2003. Análisis evolutivo de la vegetación cenozoica en las provincias de Chubut y Santa Cruz (Argentina) con especial atención en las comunidades herbáceo-arbustivas. Revista del Museo Argentino de Ciencias Naturales, 5(2):151-161

Papú, O. 1993. Nuevos hallazgos del Género Grapnelispora (Stover \& Partridge) en la Formación Loncoche de Ranquil-Co, Cretácico Superior en la Provincia de Mendoza, Argentina. Ameghiniana, 30(2):143-147.

Pascual, R.; Vucetich, M.G., \& Fernandez, J. 1978. Los primeros mamíferos (Notoungulata, Henricosborniidae) de la Fm. Mealla (Grupo Salta, Subgrupo Santa Bárbara). Sus implicancias filogenéticas, taxonómicas y cronológicas. Ameghiniana, 15(34):366-390.

Petriella, B. \& Archangelsky, S. 1975. Vegetación y ambiente en el Paleoceno de Chubut. In: CONGRESO ARGENTINO DE PALEONTOLOGÍA Y BIOESTRATIGRAFÍA, 1, 1975. Actas, Tucumán, 2:257270.

Petrulevicius, J. 1996. Una nueva localidad fosilífera del Paleoceno Superior (Formación Maíz Gordo) en el Noroeste Argentino. In: SIMPOSIO CONGRESO DEL PALEÓGENO DE AMÉRICA DEL SUR, 1, 1996. Resúmenes, La Pampa, p. 20.

Prámparo, M.B. \& Papú O.H. 2003. Palinomorfos terrestres del Maastrichtiano superior en el cerro Butaló, sur de Mendoza, Argentina. In: SIMPOSIO ARGENTINO DE PALEOBOTÁNICA Y PALINOLOGÍA, 12, 2003. Resúmenes, Buenos Aires, p. 22.

Prámparo, M.B.; Papú, O.H. \& Milana, J.P. 1995. Estudio palinológico del Miembro Inferior de la Formación Pachaco, Terciario de la Provincia de San Juan. Análisis estadístico y conclusiones paleoambientales. In: CONGRESO ARGENTINO DE PALEONTOLOGÍA Y BIOESTRATIGRAFÍA, 6, 1995. Actas, Trelew, p. 207-212.

Prámparo, M.B.; Papú, O.H. \& Milana, J.P. 1996. Estudio palinológico del Miembro Inferior de la Formación Pachaco, Terciario de la Provincia de San Juan. Descripciones sistemáticas. Ameghiniana, 33(4):397-407.

Quattrocchio, M. \& Del Papa, C. 2000. Paleoambiente de la 
Secuencia Maíz Gordo (¿Paleoceno tardío-Eoceno temprano?), Arroyo Las Tortugas, Cuenca del Grupo Salta (NO Argentina). Palinología y Sedimentología. Revista Española de Paleontología, 15(1):57-70.

Quattrocchio, M. \& Ruiz, L. 1999. Paleoambiente en base a palinomorfos de la Formación Pedro Luro (? MaastrichtianoPaleoceno), Cuenca del Colorado, Argentina. Ameghiniana, 36(1):37-47.

Quattrocchio, M.E. \& Volkheimer, W. 1990. Paleogene palaeoenvironment trends as reflected by palynological assemblage types, Salta Basin. Neues Jahrbuch für Geologie und Paläontologie, Abhandlungen, 181(1-3):377-396.

Quattrocchio, M. \& Volkheimer, W. 2000a. Paleoclimatic changes during the Paleocene-Lower Eocene, in Salta Basin, NW of Argentina. In: P. Smolka \& W. Volkheimer (eds.) Southern Hemisfere paleo-and neoclimates, Springer-Verlag, p. 353-367.

Quattrocchio, M.E. \& Volkheimer, W. 2000b. Danian microfloral provinces in Argentina. Revista Española de Paleontología, 15(1):3-11.

Quattrocchio, M.E.; Marquillas, R. \& Volkheimer W. 1988. Palinología paleoambientes y edad de la Formación Tunal, Cuenca del Grupo Salta(Cretácico Eoceno), República Argenti na. In: CONGRESO ARGENTINO DE PALEONTOLOGÍA.Y BIOESTRATIGRAFÍA, 4, 1986. Actas, Mendoza, 3: 95-107.

Quattrocchio, M.E.; Ruiz, L. \& Volkheimer, W. 2000. Palynological zonation of the Colorado and Salta basins, Argentina. Revista Española de Micropaleontología, 32(1):61-78.

Quattrocchio, M.; Volkheimer, W. \& Del Papa, C. 1997: Palynology and paleoenvironment of the "Faja Gris" Mealla Formation (Salta Group) at Garabatal Creek (NW Argentina). Palynology, 21:31-247.

Quattrocchio, M.E.; Volkheimer, W.; Marquillas, R.A. \& Salfity, J.A. 2005. Palynostratigraphic, palaeobiogeographic an evolutionary significance of the Late Senonian and Early Paleogene floras of northern Argentina". Revista Española de Micropaleontología, 37(2): 259-272.

Rojero, F.F. 2000. ¿ Una asignatura sistémica o sistemática?. A systemic or systematic subject? Enseñanza de las Ciencias de la Tierra, 8(3):189-196.

Romero, E.J. 1973. Polen fósil de "Nothofagus" ("Nothofagidites") del Cretácico y Paleoceno de Patagonia. Revista del Museo de La Plata, nueva serie, Paleontología, 7:291-303.

Romero, E.J. 1977. Polen de angiospermas y fagáceas de la Formación Río Turbio (Eoceno), Santa Cruz, Argentina. Buenos Aires, Unidad de Paleobotánica y Palinología, Centro de Investigaciones en Recursos Geológicos, 219 p.

Romero, E.J. 1978. Paleoecología y paleofitogeografía de las tafofloras del Cenofítico de Argentina y áreas vecinas. Ameghiniana, 15(1-2):209-227.

Romero, E.J. 1986. Paleogene phytogeography and climatology of South America. Annals of the Missouri Botanical Garden, 73:449-461.
Romero, E.J. \& Zamaloa, M.C. 1985. Polen de angiospermas de la Formación Río Turbio (Eoceno), provincia de Santa Cruz, Argentina. Ameghiniana, 22(1-2):43-51.

Rosello, E.A;Ottone, E.G.; Haring, C.E. \& Nevistic, V.A. 2004. Significado tectónico y paleoambiental de los niveles carbonosos paleógenos de Estancia La Correntina, Andes Fueguinos. Revista de la Asociación Geológica Argentina, 59(4):778-784.

Ruiz, L. 1993. Estatigrafia y paleoambientes en base a palinomorfos de la Formación Pedro Luro (Maastrichtiano-Paleoceno) en la Cuenca del Colorado, República Argentina. Universidad Nacional del Sur, Bahía Blanca, Doctoral Thesis. 170 p.

Ruiz, L. \& Quattrocchio, M. 1996. Stratigraphic palynology of Pedro Luro Formation (?Maastrichtian-Paleocene), Colorado Basin. Argentine. Elf Aquitaine. Mémoire 16:361-371.

Ruiz, L. ; Quattrocchio, M.; Guerstein, G.R. \& Volkheimer, W. 1999. Rangos estratigráficos de palinomorfos del Paleógeno de Argentina, Antártida y Chile. Anales de la Dirección Nacional del Servicio Geológico, 23:88-103.

Salfity, J.A.; Marquillas, R.; Gardeweg, M.; Ramirez, C.\& Davidson, J. 1985. Correlaciones en el Cretácico Superior del norte de Argentina y Chile. In: CONGRESO GEOLÓGICO CHILENO, 1985. Actas, Antofagasta, 4:1654-1667.

Sepúlveda, E.; Papú, O.H. \& Volkheimer, W. 1989. Importancia estratigráfica y paleobiogeográfica del género Grapnelispora (Stover \& Partridge), en el Cretácico tardío del hemisferio austral. Boletín IG-USP, Publicação Especial, 7:163-171.

Traverse, A. 1988. Paleopalynology. Unwin Hyman Ltd, 600 p.

Uliana, M.A. \& Biddle, K.T. 1988. Mesozoic-Cenozoic paleogeographic and geodynamic evolution of southern South America. Revista Brasileira de Geociências, 18(2):172-190.

Villagrán, C. \& Hinojosa, L.F. 1997. Historia de los bosques del sur de Sudamérica, II: Análisis fitogeográfico. Revista Chilena de Historia Natural, 70:241-267.

Volkheimer, W. 1971. Aspectos paleoclimatológicos del Terciario Argentino. Revista Museo Argentino de Ciencias Naturales “Bernardino Rivadavia”, 8:241-264.

Zinsmeister, W.J. 1979. Biogeographic significance of the Late Mesozoic and early Tertiary molluscan faunas of Seymour Island (Antarctic Peninsula) to the final breakup of Gondwanaland. In: J. Gray \& A.J. Boucot (eds.) Historical Biogeography, Plate Tectonics and the Changing Environment, University Press, p. 349-355.

Zinsmeister, W.J. 1982. Late Cretaceous-Early Tertiary molluscan biogeography of the southern CircumPacific. Journal of Paleontology, 56:84-102.

Zubakov, V.A. \& Borzenkova, I.I. 1990. Global paleoclimate of the Late Cenozoic. Developments in Palaeontology and Stratigraphy, 12:1-456.

Received in January, 2006; accepted in March, 2006. 